\title{
Kritisk diskursanalyse
}

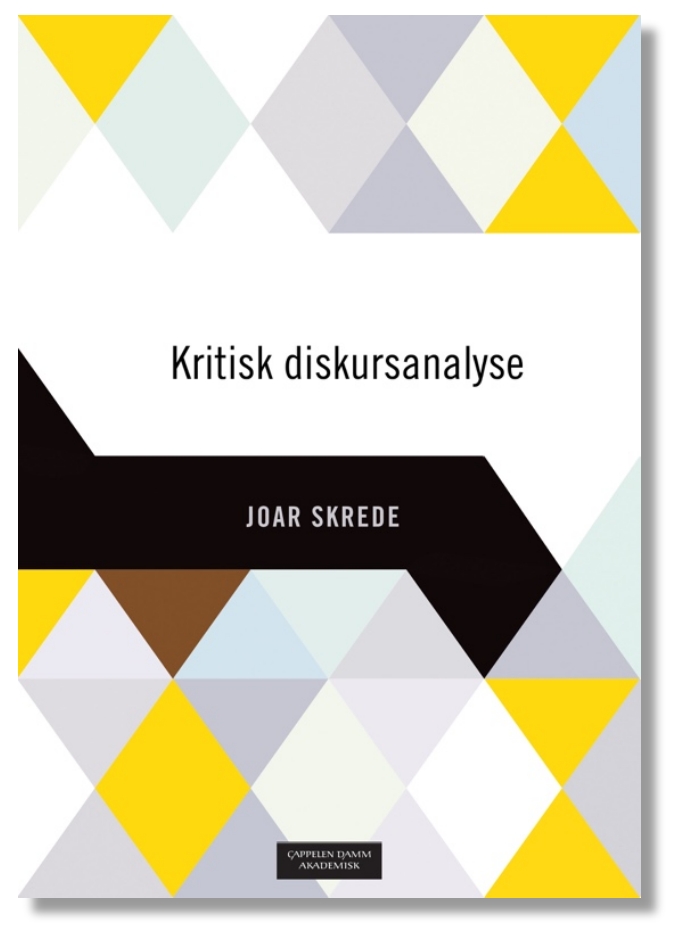

Joar Skrede (2017).

Kritisk diskursanalyse.

Oslo: Cappelen Damm Akademisk, 187 sider.

Det er ikke skrevet særlig mange bøker av nordiske forfattere om diskursanalyse, trass i den store interessen for diskursperspektiver og diskursteoretiske begreper blant forskere og studenter $\mathrm{i}$ samfunnsfagene. Sosiologen Joar Skredes bok Kritisk diskursanalyse (Cappelen Damm Akademisk, 2017) er et av de få nyere bidragene. Boka tar for seg en spesiell retning innenfor det diskursanalytiske landskapet. Som bokas tittel signaliserer, dreier det seg om såkalt kritisk diskursanalyse.

Det kan selvsagt med god grunn hevdes at diskursanalyse generelt er kritisk av natur. Den retningen som kalles kritisk diskursanalyse, har imidlertid etablert seg som en særskilt tradisjon. Den forbindes ofte med forskere som Norman Fairclough, Ruth Wodak og Teun van Dijk. Kritisk diskursanalyse er kanskje mindre kjent i Norge enn diskursanalytiske tilnærminger inspirert av Michel Foucault, Ernesto Laclau, Chantal Mouffe og andre poststrukturalistiske tenkere. Kritisk diskursanalyse har hentet viktig inspirasjon fra poststrukturalismen og sosialkonstruktivismen, men vitenskapsfilosofisk sokner den til en annen retning, nemlig kritisk realisme. Kritisk diskursanalyse er blant annet ikke så radikalt kunnskapsrelativistisk som den Foucault-inspirerte tradisjonen. Kritisk diskursanalyse bruker også diskursbegrepet i noe snevrere mening enn i en del andre diskursanalytiske tilnærminger. Mens diskursbegrepet i flere av de poststrukturalistiske retningene omfatter ikke bare tekster, tegn og meningsytringer, men også sosial praksis i bredere forstand, fokuserer kritisk diskursanalyse først og fremst på tekster og visuelle uttrykk. Til gjengjeld går kritisk diskursanalyse ofte dypere inn i de lingvistiske aspektene enn enkelte andre varianter av diskursanalyse.

Joar Skredes bok er en velskrevet og lett forståelig innføring i kritisk diskursanalyse. På 187 korte sider forteller Skrede om framveksten av og grunnprinsippene i kritisk diskursanalyse, det vitenskapsteoretiske grunnlaget den bygger på, og om såkalt multimodal kritisk diskursanalyse. Forfatteren gir konkrete eksempler på bruk av både tradisjonell språklig 
diskursanalyse og den multimodale varianten, som omfatter analyse av både tekst og bilder (inklusiv tredimensjonale visuelle uttrykk som $\mathrm{f}$. eks. arkitektonisk materialbruk og form). Sentralt i denne delen står en multimodal analyse forfatteren selv har foretatt av nyliberaliseringen av norsk kulturpolitikk. Til slutt i boka diskuterer Skrede noen kritikkpunkter som har blitt reist mot diskursanalyse som metode og utfordringer de som benytter denne metoden kan støte på i analysen.

Skrede er tydelig på at kritisk diskursanalyse ikke er en politisk nøytral eller «uskyldig» metode. Kritisk diskursanalyse går generelt ut på å avdekke hvordan språk bidrar til å opprettholde maktforhold i samfunnet. Det er først og fremst bruk av språk og bilder som opprettholder kritikkverdige maktforhold kritisk diskursanalyse fokuserer på. Det er dette som ligger i at diskursanalysen er kritisk. Et slikt kritisk blikk er likevel ikke noe som den retningen som kaller seg kritisk diskursanalyse er alene om. Også f. eks. Foucault- eller Mouffe-inspirerte diskursanalyser er som regel kritiske i forhold til de maktinteressene som støttes av diskursene de analyserer. Hva som oppfattes som kritikkverdig, avhenger selvsagt i stor grad av «øynene som ser». Felles for kritisk diskursanalyse og mer poststrukturalistisk orienterte former for diskursanalyse, er at kritikken ofte retter seg mot fenomener som rasisme, sexisme, kolonialisme, globalisering og kommersialisering. Det normative utgangspunktet ligger med andre ord ofte til venstre i det politiske landskapet. Det gjelder også Skredes eksempel fra egen forskning (nyliberalistisk kulturpolitikk) og ikke minst eksemplene han gjengir fra en av den kritiske diskursanalysens absolutte frontfigurer, Norman Fairclough. Skrede peker samtidig på at det kritiske formålet ikke nødvendigvis må komme fra et venstreorientert politisk ståsted.

Det er Faircloughs versjon av kritisk diskursanalyse Skrede legger mest vekt på å presentere. Fairclough, med sin «dialektisk-relasjonelle» tilnærming, er ifølge Skrede den som i størst grad har preget kritisk diskursanalyse som forskningstradisjon. Det språklige elementet står sentralt hos Fairclough, men Fairclough understreker samtidig at systematisk analyse av tekster må kombineres med analyse av hvordan språkbruken har en ideologisk funksjon og bidrar til å legitimere bestemte samfunnspraksiser og maktforhold. Kritisk diskursanalyse krever at forskeren trekker inn andre samfunnsvitenskapelige teorier i tillegg til rent språkanalytiske verktøy. Skrede viser med eksempel fra en analyse av Tony Blairs politiske dokumenter (en melding til parlamentet om «kunnskapsøkonomien») hvordan Fairclough selv har praktisert diskursanalyse etter denne oppskriften. Skrede gjør oppmerksom på at Fairclough har erstattet sin opprinnelige analysemodell (med sosial praksis, diskursiv praksis og tekst som de tre sentrale begrepene) med en ny modell der de sentrale begrepene er sosial struktur, sosial praksis og sosiale begivenheter. Ifølge Skrede overser de fleste lærebøkene som omtaler Faircloughs kritiske diskursanalyse denne endringen. Skrede framholder at det nye begrepsapparatet på en klarere måte reflekterer at tekster er en del av sosiale begivenheter, og at det egner seg bedre til å analysere samfunnsmessig praksis ikke bare på mikronivå, men også på makronivå knyttet til økonomiske strukturer, maktforhold, byråkrati osv. Det nye begrepsapparatet harmonerer ifølge Skrede også bedre med det vitenskapsteoretiske utgangspunktet i kritisk realisme.

Som nevnt gjennomgår Skrede $\mathrm{i}$ et av kapitlene det vitenskapsteoretiske fundamentet kritisk diskursanalyse bygger på. Både strukturalisme, poststrukturalisme, sosialkonstruktivisme og kritisk realisme blir omtalt, med hovedvekt på den siste posisjonen. Forfatteren framholder at kritisk realisme inkorporerer viktige innsikter fra de tre førstnevnte posisjonene, samtidig som den unngår deler forfatteren oppfatter som problematiske. Kunnskapsrelativismen som ofte preger poststrukturalistisk og sosialkonstruktivistisk litteratur er allerede nevnt. Kritisk realisme legger dessuten vekt på betydningen av sosiale makrostrukturer, bl.a. som forholdsvis stabile forutsetninger for utøvelse av makt. Kritisk realisme skiller seg her fra maktforståelsen hos f. eks. Foucault, som så på makt som noe som bare eksisterer i selve utøvelsen og ikke noe man kan inneha i kraft av ens samfunnsmessige posisjon. Skrede framhever dessuten at kritisk realisme, i likhet med kritisk diskursanalyse, legger vekt på å avdekke hvordan samfunn produserer både fordelaktige og uheldige resultater. Noen samfunnsmessige fenomener oppfattes av de fleste som 
uheldige. Ved å avdekke årsaker og mekanismer bak uønskete og unødvendige samfunnsfenomener, kan kritisk diskursanalyse gi grunnlag for å foreslå hvordan samfunnsutviklingen kan forbedres.

Faircloughs egne analyser fokuserer først og fremst på skrevne tekster. Skrede vier imidlertid to kapitler til en innføring i multimodal og tredimensjonal kritisk diskursanalyse, illustrert med et rikt bildemateriale.

Skredes bok om kritisk diskursanalyse er et kjærkomment bidrag til litteraturen på dette feltet. Den supplerer internasjonale bidrag som f. eks. Wodak og Meyers bok «Methods of critical discourse analysis» fra 2009. Skredes språklige framstillingsevne er svært god, uten unødvendig sjargong og uten lange, kompliserte setninger. Spesielle faglige begreper forklares etter hvert som de dukker opp, og forfatteren viser et betydelig pedagogisk talent i måten stoffet er disponert og forklart på. Boka er derfor forståelig også for lesere uten omfattende forkunnskaper. Den lever godt opp til målsettingen om å illustrere hvordan maktrelasjoner i samfunnet kan reproduseres gjennom visse måter å ordlegge seg på og gjennom visuell form. Boka gir dessuten en rekke verktøy, begreper og eksempler som kan gjøre leseren i stand til selv å utføre kritisk diskursanalyse. En slik «oppskriftsbok» har lenge vært mangelvare ikke bare i Norge, men også i internasjonal sammenheng.

Jeg anbefaler boka både til ferske studenter og mer erfarne akademikere.

Joar Skrede (2017).

Kritisk diskursanalyse

Oslo: Cappelen Damm Akademisk, 187 sider.

\section{Petter Næss}

Professor

Norges miljø- og biovitenskapelige universitet,

Fakultet for landskap og samfunn, Institutt for by- og regionplanlegging

petter.nass@nmbu.no 